\title{
ESCHERICHIA COLI ENCODING EXTENDED-SPECTRUM BETA-LACTAMASES ISOLATED FROM DIARRHEIC PATIENTS IN MINNA, NIGERIA
}

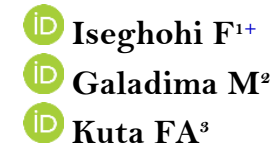

Kuta FA ${ }^{3}$

\author{
${ }^{\prime}$ Medical Biotechnology Department, National Biotechnology Development \\ Agency, Abuja, Nigeria. \\ 'Email: gigicloudy@yahoo.com Tel: +234-8035820797 \\ ${ }^{2, s}$ Department of Microbiology, Federal University of Technology, Minna, \\ Nigeria. \\ ${ }^{2}$ Email: pyata50@gmail.com Tel: +234-8034509268 \\ ${ }^{3}$ Email:farukkuta@gmail.com Tel:+234-7032738427
}

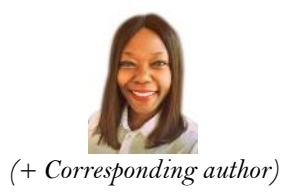

(+ Corresponding author)

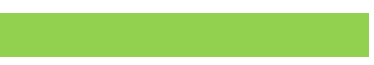

\section{Article History}

Received: 21 May 2021 Revised: 24 June 2021

Accepted: 4 August 2021

Published: 16 September 2021

\section{Keywords}

Escherichia coli

Diarrhea

ESBL

Multidrug resistance

Minna

OXA

CTX-M

TEM.

\section{ABSTRACT}

Escherichia coli remains one of the most isolated etiological agents of diarrhea, accounting for more than 1 million deaths and about $4 \%$ of the total global disabilityadjusted life-years (DALYS) per year across all age groups according to the global disease burden. This study evaluated multidrug-resistant Escherichia coli encoding extended spectrum beta-lactamases isolated from diarrheic patients in Minna, Nigeria using standard microbiological methods. A prevalence of $37.7 \%$ of Diarrheagenic E. coli (DEC) was obtained from the stool samples evaluated. Within the environment sampled, age group $21-30$ years had the highest $E$. coli isolation rate (27.8\%) while age group $\geq 71$ years had the least $E$. coli isolation rate $(2.6 \%)$. Females $(64.9 \%)$ were the most affected compared to males (35.1\%). The isolates were significantly resistant to most of the beta-lactams tested especially to $3^{\text {rd }}$ generation cephalosporins [Cefotaxime (98.2\%), cefuroxime (93\%), ceftazidime (84.2\%), Augmentin (70.2\%), Amoxicillin $(59.6 \%)]$. Resistance to other classes of antibiotics was also observed in varying percentages. A high percentage $(98.2 \%$ and $87.7 \%)$ of the diarrheagenic $E$. coli had a multiple resistant index $(\mathrm{MARI}) \geq$ of 0.3 . The isolates had varying patterns of resistance with $47.6 \%$ resistant to more than 5 classes of antibiotics tested and produced ESBL characteristics phenotypically. Molecular evaluation showed that $40 \%$, $50 \%$, and $90 \%$ of the isolates harbored the OXA, CTX-M and TEM genes respectively while 50\% harbored VEB and PER genes. This study isolated E. coli from diarrheic patients with multidrug resistance profiles and encodes more than one type of ESBL gene within Minna, Nigeria.

Contribution/Originality: This study established the prevalence and multidrug resistance profile patterns of Escherichia coli encoding ESBL genes from diarrheic patients in Minna, Nigeria. The findings also revealed a genetic diversity of ESBL genes responsible for significant resistance of Diarrheagenic E. coli to most of the beta-lactams and other classes of antibiotics.

\section{INTRODUCTION}

Escherichia coli (E. coli) are a vital commensal Enterobacteriaceae in the gastrointestinal tract of humans and animals. Nevertheless, some pathogenic strains have emerged with multidrug-resistant (MDR) and virulent characteristics that consequently result in significant public health diseases including diarrhea (Margulieux et al., 2018). One of such strains mostly implicated in diarrhea is the Enterotoxigenic E. coli(ETEC) that produces 1-3 enterotoxins, which spontaneously results in acute diarrhea in infants and traveler's disease worldwide (Kantele et 
al., 2020; Pandey et al., 2011). This strain operates by attaching itself to the small intestinal wall along the epithelial surface and colonizes the cells using its colonization factors (CFs) (Vipin \& Sakellaris, 2015). This results in the production of heat-stable enterotoxins (STh or STP) and/or heat-labile enterotoxins (LT) which interfere with crucial cellular mechanisms resulting in abdominal cramps and watery stool (Isidean, Riddle, Savarino, \& Porter, 2011). In addition, the other strains of Diarrheagenic E. coli (DEC), notably O157:H7, O104:H4, O121, O26, O103, $\mathrm{O} 111, \mathrm{O} 145$, and $\mathrm{O} 104: \mathrm{H} 21$ have been reported to elicit potential lethal toxins resulting in diarrheic diseases (Shridhar et al., 2018). Other serotypes also associated with diarrhea are Enterohemorrhagic E. coli (EHEC) Enteroaggregative E. coli (EAEC) Enteroinvasive E. coli (EIEC) and Enteropathogenic E. coli (EPEC) (Croxen et al., 2013). ETEC remains the most prevalent enteropathogenic E.coli common in developing countries, resulting in about 210 million diarrhea cases and nearly 380,000 deaths (Archana, O`Keefe, Cuthill, Varman, \& Kumar, 2019). Clinical manifestation of EIEC includes crampy abdominal pain, bloody mucoid diarrhea with fever, and tenesmus in infected individuals (Archana et al., 2019). About Ten percent (10\%) of patients with EHEC frequently come down with hemolytic uremic syndrome (HUS) as a result of the serotype 0157:H7. HUS is mostly accompanied by acute renal failure, hemolytic anemia and thrombocytopenia. According to the Centre for Disease Control and Prevention (2013), these classes of E. coli are established as prominent international public health threats, and transmission of virulence properties is through ingestion of pathogen infected food or water, or contact with diseased animals or infected persons. Most worrisome is the endemic nature of these strains and serotypes in developing countries including Nigeria as they contribute to high rates of mortality and morbidity especially in neonates (Ghorbani-Dalini, Kargar, Doosti, Abbasi, \& Sarshar, 2015). Statistical evaluation of various diseases has shown that diarrhea is the second primary cause of death in children under 5 years of age and over 525000 children die annually (Mandal et al., 2017). Diarrhea caused by E.coli can be avoided by maintaining good hygienic practices and breast feeding of infants in ETEC endemic regions. The diarrhea is best managed through administering of oral fluid and electrolyte replacement (intravenous in severe cases) to infected individuals. Use of antibiotics is discouraged as it can lead to spread of antibiotic-resistant pathogenic $E$ coli and other deadly enteropathogens (Todar, 2020). Interestingly, diarrheagenic E. coli (DEC) has been revealed to possess resistance to some antimicrobial agents such as extended spectrum beta-lactamases (ESBL) encoding genes (Ogefere, Ibadin, Omoregie, \& Ilerhunwa, 2016). DEC encoding ESBLs causes resistance to the commonly prescribed beta-lactam antibiotics, for example, the $3^{\text {rd }}$ and $4^{\text {th }}$ generations' cephalosporins such as ceftriaxone, ceftazidime, cefotaxime, cefuroxime, and cefixime. This, however, degenerates to failure in therapeutic outcomes in human and animal medicine (Lee \& Yeh, 2017). Interestingly, Bushand and Jacoby (2010) have reported the capability of clavulanic acid, sulbactam, and tazobactam to inhibit ESBLs. The most commonly isolated ESBL genes include TEM, SHV, and CTX-M (Igwe et al., 2014). A study by Gniadkowski (2008) reported that all CTX-M-types are enzymatic, while the TEM and SHV types occur as a result of a point mutation at specific residues from the natural TEM1/TEM-2 and SHV-1 $\beta$-lactamase respectively. Studies by Igwe et al. (2014); Pitout and Laupland (2008) have shown that ESBLs are plasmid-mediated and these plasmids also bear genes that encode resistance to other classes of antimicrobials, for example fluoroquinolones and aminoglycosides. Therefore, this is to determine the prevalence of ESBL producing E. coli among diarrheic patients in Minna metropolis.

\section{MATERIALS AND METHODS}

\subsection{Study Area}

Stool samples were obtained from the diagnostic laboratories of four (4) different hospitals in Minna metropolis. The hospitals include Standard Hospital, Old airport road, Top Medical Clinic, Tunga, Ibrahim Badamosi Babangida (IBB) Specialist Hospital, Chachanga, and General Hospital, Minna. Stool samples were also obtained from healthy individuals which served as control. Figure 1 is the Map showing the locations where samples were collected within Minna Metropolis, Niger State as captured by Google (2020) is shown below: 


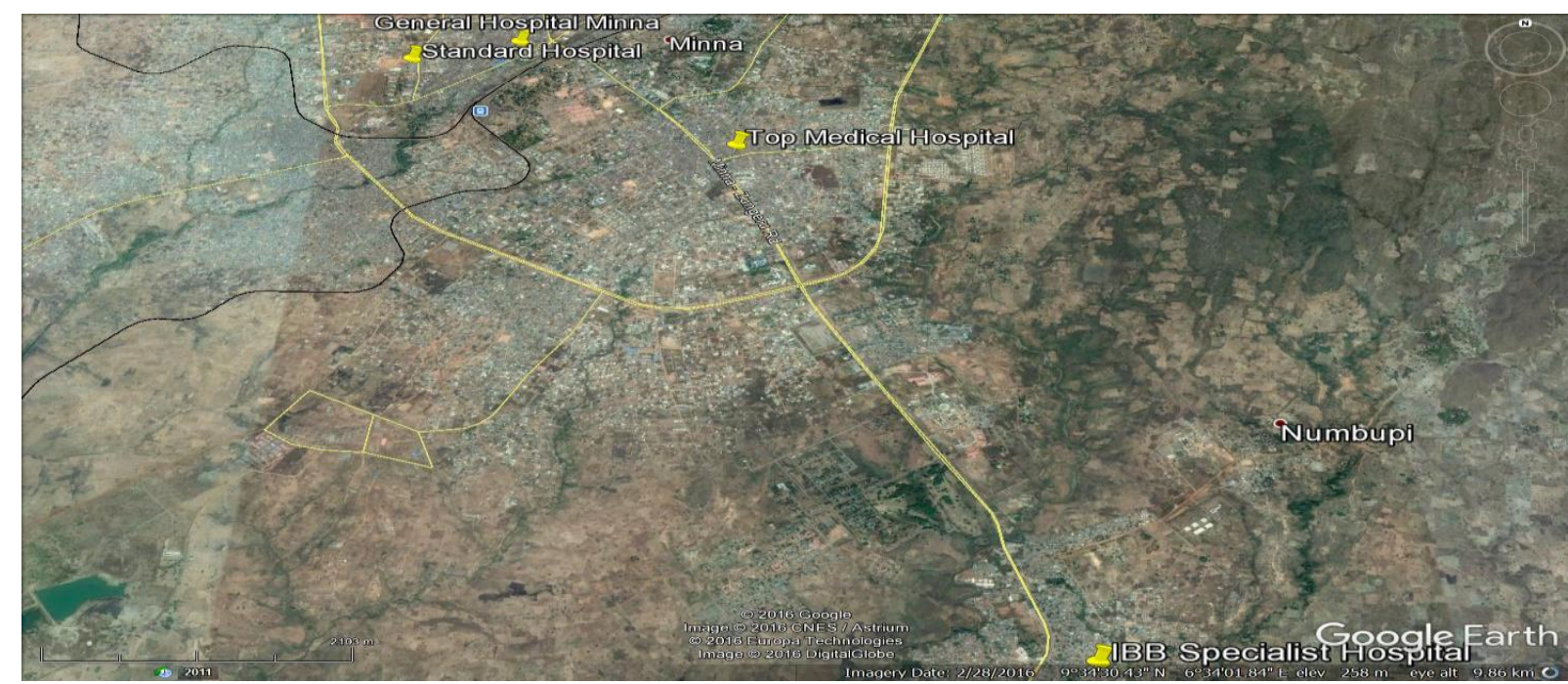

Figure-1. Locations of the four hospitals in Minna metropolis, Niger State.

\subsection{Determination of Sample Size}

The single proportion method was used to determine the sample size with a $6.9 \%$ prevalence rate as described by Onanuga, Igbeneghu, and Lamikanra (2014).

$\begin{aligned} \mathrm{n}=\mathrm{Z} \quad(1-\mathrm{P}) \quad & \text { Where } \mathrm{n}=\text { size of the sample } \\ \mathrm{Z} & =1.96 \text { for Confidence level at } 95 \% \\ & \mathrm{P}=\text { rate of prevalence at } 6.9 \% \\ & \mathrm{D}=0.05 \text { for Marginal error at } 5 \% \\ & \text { The sample size was calculated as } 98.7 \text {, rounded up to } 120 .\end{aligned}$

\subsection{Ethical Clearance}

Ethical authorization for this study was issued by the Research Ethics Committee, General Hospital, Minna, Niger State with the registration number HMB/GHM/STA/136/VOL.II/350, dated $29^{\text {th }}$ October 2015.

\subsection{Specimen Collection and Processing}

A total of 120 samples of loose or watery stool passed by diarrheic patients and submitted to the Microbiology Laboratory of the four hospitals in Minna metropolis were randomly obtained within 5 months i.e. May September 2015. The samples were carefully transported to the laboratory of the Microbiology Department, Federal University of Technology (F.U.T), Minna in an ice pack within 40 minutes of collection for further analysis.

\subsection{Isolation and Identification of Escherichia coli}

Using a sterile wire loop, a loopful of each stool sample was picked and streaked onto sterilized Eosin methylene blue (EMB) agar and MacConkey agar (MCA) followed by incubation at $37^{\circ} \mathrm{C}$ for 24 hours. Identification of suspected isolates of $E$. coli was done based on morphological and cultural characteristics, sugar fermentation, Gram's reaction, and series of biochemical tests such as lysine decarboxylase, motility, triple sugar iron, citrate utilization, urease production, Voges-Proskauer, methyl red, and indole test were all carried out as described by Cheesbrough (2006).

\subsection{Antibiotic Susceptibility Test}

The confirmed E.coli isolates were screened using 13 frequently prescribed antibiotics used for the treatment of E. coli related infections. This test technique was carried out according to Cheesbrough (2006) and results were interpreted using CLSI (2016) as shown in Table 1. 
The International Journal of Biotechnology, 202 1, 10(2): 52-68

Table-1. Clinical laboratory science index interpretation for selected antibiotics.

\begin{tabular}{|c|c|c|c|c|}
\hline \multirow[t]{2}{*}{$\mathbf{S} / \mathbf{N}$} & \multirow[t]{2}{*}{ Beta-Lactam Antibiotics } & \multicolumn{3}{|c|}{ Zone of Inhibition ( $\mathrm{mm}$ ) } \\
\hline & & Susceptible & Intermediate & Resistance \\
\hline 1 & Ceftazidime $(30 \mu \mathrm{g})$ & $\geq 18$ & $15-17$ & $\leq 14$ \\
\hline 2 & Cefotaxime $(30 \mu g)$ & $\geq 23$ & $15-22$ & $\leq 14$ \\
\hline 3 & Cefuroxime $(30 \mu g)$ & $\geq 18$ & $15-17$ & $\leq 14$ \\
\hline 4 & Amoxicillin $(30 \mu g)$ & $\geq 17$ & $14-16$ & $\leq 13$ \\
\hline 5 & Augmentin (10/20 $\mu g)$ & $\geq 18$ & $14-17$ & $\leq 13$ \\
\hline 6 & Cotrimoxazole ( $7 / 23 \mu g)$ & $\geq 16$ & $11-15$ & $\leq 10$ \\
\hline 7 & 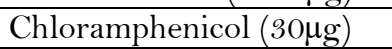 & $\geq 18$ & $13-17$ & $\leq 12$ \\
\hline 8 & 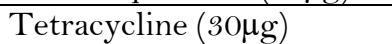 & $\geq 15$ & $12-14$ & $\leq 11$ \\
\hline 9 & Ciprofloxacin $(5 \mu g)$ & $\geq 21$ & $16-20$ & $\leq 15$ \\
\hline 10 & Gentamicin $(10 \mu g)$ & $\geq 15$ & $14-15$ & $\leq 12$ \\
\hline 11 & Streptomycin $(30 \mu g)$ & $\geq 15$ & $12-14$ & $\leq 11$ \\
\hline 12 & Pefloxacin $(10 \mu \mathrm{g})$ & $\geq 21$ & $16-20$ & $\leq 15$ \\
\hline 13 & Ofloxacin $(10 \mu g)$ & $\geq 16$ & $13-15$ & $\leq 12$ \\
\hline
\end{tabular}

2.7. Determination of Multiple Antibiotic Resistance (MAR) Index

The MAR of each isolated E.coli was determined utilizing the method of Krumperman (1983).

MAR Index $=\underline{\text { Number of antibiotics to which isolate is resistant to }}$

Total number of antibiotics tested

\subsection{Presumptive Test for Extended-Spectrum Beta-Lactamase (ESBL) Production}

The double disc synergy test as described by Igwe et al. (2014) was adopted to confirm the production of ESBL by the E. coli isolates. The confirmed E. coli isolates which exhibited multidrug-resistant features were standardized to 0.5 McFarland turbidity standard using phosphate buffered saline. Each confirmed isolate was first suspended in broth culture and incubated overnight. The inoculum of each isolate was taken from each broth culture and inoculated uniformly on nutrient agar then incubated at $37^{\circ} \mathrm{C}$ for $24 \mathrm{~h}$. A $0.5 \mathrm{McF}$ arland turbidity standard was prepared for the standardization of inoculums $\left(1-2 \times 10^{5} \mathrm{cfu} / \mathrm{ml}\right)$. Well isolated colonies of E.coli were picked from nutrient agar and emulsified in test tubes containing $5 \mathrm{ml}$ sterile saline. Under good lighting, the turbidity of the test suspension was compared with 0.5 McFarland turbidity standard. Using swab sticks, the standardized cultures were uniformly streaked on sterile Mueller Hinton Agar (MHA) plates and allowed to dry at room temperature for 5minutes. Sterile forceps were used to carefully place antibiotic discs containing amoxicillin-clavulanate

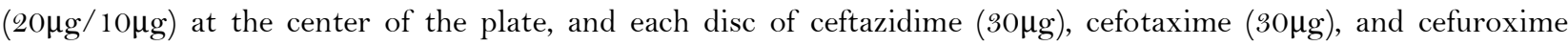
$(30 \mu \mathrm{g})$ were positioned $20 \mathrm{~mm}$ (center to center) from the amoxicillin-clavulanate disc. The MHA plates were incubated at $37^{\circ} \mathrm{C}$ for $24 \mathrm{~h}$. Control used was E. coli ATCC 25922 , authorized by the Clinical and Laboratory Standard Institute (CLSI) as a reference strain for detection of ESBL production.

The positive results obtained for the production of ESBL by test isolates were interpreted following CLSI procedures. Positive results were interpreted as isolates that exhibited a distinct shape/size with potentiation towards amoxicillin + clavulanic disc with a $\geq 5 \mathrm{~mm}$ increase in zone diameter for either antimicrobial agent compared to its zone when tested alone. Additionally, any isolate that had the zone of inhibition around the test antibiotic disc extended towards the center disc of amoxicillin-clavulanic acid is presumed positive.

\subsection{Molecular Characterization of Extended-Spectrum Beta-Lactamase Resistant Escherichia Coli}

\subsubsection{Bacterial Cell Preparation}

The bacteria cells were prepared for molecular analysis using the procedure described by Igwe et al. (2014). Luria and Bertani broth medium were prepared by dissolving $10 \mathrm{~g}$ of peptone water, $5 \mathrm{~g}$ of $\mathrm{NaCl}, 1 \mathrm{ml}$ of $1 \mathrm{~N} \mathrm{NaOH}$, $5 \mathrm{~g}$ of yeast extract in 1litre of distilled water. $\mathrm{NaOH}$ was used in adjusting the $\mathrm{pH}$ of the solution to 7.0 before 
sterilization at $121^{\circ} \mathrm{C}$ for $15 \mathrm{mins}$. A loopful of each multidrug-resistant isolate of $E$. coli was inoculated in $5 \mathrm{~mL}$ of Luria and Bertani (LB) broth and incubated at $37^{\circ} \mathrm{C}$ for 24 hours.

\subsection{DNA Extraction}

The extraction of DNA was accomplished following the manufacturer's instructions as described on the Bioneer Accuprep ${ }^{\circledR}$ GMO DNA Extraction Kit. The resistant E.coli isolates suspended in Luria broth were centrifuged for 1 minute at 6000rpm before harvesting the cell pellets. The harvested cell pellets were again suspended in $200 \mu \mathrm{l}$ of phosphate-buffered saline (PBS) and subsequently transferred to a falcon tube comprising 20 $\mu \mathrm{l}$ of Protinease $\mathrm{K}$ and vortexed for 10secs. The cells were lysed by placing the falcon tubes in a water bath for $10 \mathrm{mins}$ at $55^{\circ} \mathrm{C} .100 \mu \mathrm{l}$ of absolute ethanol was dispensed into the falcon tubes and placed on a rack to stand for 2 mins. A micropipette was used to transfer $600 \mu \mathrm{l}$ of cell lysate into a binding column and centrifuged for $1 \mathrm{~min}$ at 8000rpm. After centrifugation, the binding column was transferred into a new binding column, and the supernatant was discarded. $500 \mu \mathrm{l}$ of washing buffer 1 was added into the new binding column and centrifuged for 2 minutes at $8000 \mathrm{rpm}$. Thereafter, the binding column was transferred into another binding column and supernatant discarded, $500 \mu \mathrm{l}$ of washing buffer 2 was added into the new binding column and centrifuged for 1 minute at $8000 \mathrm{rpm}$. The binding column was taken out and the supernatant discarded. To remove excess water and ethanol, the column was centrifuged for 1 minute at 13000 rpm. To the binding column, $50 \mu \mathrm{l}$ elution buffer was added and placed on a rack to stand for 1 minute before centrifuging for 2 minutes at $10000 \mathrm{rpm}$ to enable the dissolved DNA to settle at the base of the binding column. For analysis and preservation, extracted DNA was suspended in elution buffer (Bioneer, 2004).

\subsection{Detection and Characterization of Resistant Genes Using Polymerase Chain Reaction}

Polymerase chain reaction (PCR) was used to amplify the target genes from extracted plasmid DNA. Table 2 constitutes specific gene primers used for the amplification of specific gene fragments responsible for coding betalactamase resistance in E. coli. This process was performed utilizing Dream Taq ${ }^{\mathrm{TM}}$ PCR master mix (2x), thawed, vortexed, and centrifuged at $10000 \mathrm{rpm}$ for 30 seconds. To constitute $50 \mu \mathrm{l}$ volume reaction; $10.0 \mu \mathrm{l}$ of template DNA (plasmid DNA), $1.0 \mu \mathrm{l}$ of the forward primer, $1.0 \mu \mathrm{l}$ of the reverse primer, $13 \mu \mathrm{l}$ nuclease-free water and $25 \mu \mathrm{l}$ of Dream Taq ${ }^{\mathrm{TM}}$ PCR master mix were aliquoted into an Eppendorf tube, vortexed and spun. PCR conditions utilized are stated in Table 3.

Table-2. Extended-spectrum beta-lactamase primers.

Below is the nucleotide sequence of primers and size of each ESBL Gene respectively.

\begin{tabular}{|c|c|c|c|}
\hline Gene & Sequence & Amplicon size (bp) & Reference \\
\hline TEM & $\begin{array}{l}\text { F: 5'ATTCTTGAAGACGAAAGGGCCTC3' } \\
\text { R: 5'TTGGTCTGACAGTTACCAATGC3' }\end{array}$ & 931 & Igwe et al. (2014) \\
\hline $\mathrm{SHV}$ & $\begin{array}{l}\text { F: 5'GCCGGGTTATTCTTATTTGTCCG3' } \\
\text { R:5' ATGCCGCCGCCAGTCA3' }\end{array}$ & 868 & Igwe et al. (2014) \\
\hline $\begin{array}{l}\text { CTX- } \\
\mathrm{M}\end{array}$ & $\begin{array}{l}\text { F: 5'CGCTTTGCGATGTGCAG3' } \\
\text { R: 5'ACCGCGATATCGTTGGT3' }\end{array}$ & 593 & Monstein et al. (2007) \\
\hline OXA & $\begin{array}{l}\text { F:5'AAGAAACGCTACTCGCCTGC3' } \\
\text { R: 5'CCACTCAACCCATCCTACCC3' }\end{array}$ & 478 & Igwe et al. (2014) \\
\hline PER & $\begin{array}{l}\text { F: 5'GCAACTGCTGCAATACTCGG3' } \\
\text { R: 5'ATGTGCGACCACAGTACCAG3' }\end{array}$ & 716 & Guessennd et al. (2008) \\
\hline VEB & $\begin{array}{l}\text { F:5'CGACTTCCATTTCCCGATGC3' } \\
\text { R:5'GGACTCTGCAACAAATACGC3' }\end{array}$ & 542 & Guessennd et al. (2008) \\
\hline
\end{tabular}

Oxacillin hydrolyzing, CTX-M = Cefotaxime hydrolyzing, $\mathrm{G}=$ Guanine, $\mathrm{T}=$ Thymine, $\mathrm{C}=$ Cytosine, $\mathrm{A}=$ Adenine, $\mathrm{bp}=\mathrm{base}$ pair 
Table-3. PCR thermal cycling conditions used.

\begin{tabular}{|c|c|c|c|}
\hline Step & Temperature $\left({ }^{\circ} \mathrm{C}\right)$ & Time & Number of Cycles \\
\hline Initial denaturation & 94 & 5 minutes & 1 \\
\hline Denaturation & 94 & $30 \mathrm{sec}$ & 35 cycles \\
\hline Annealing & $\begin{array}{c}68 \text { (SHV) } \\
55 \text { (TEM) } \\
60 \text { (CTX-M) } \\
50 \text { (OXA) } \\
65(\mathrm{PER}) \\
65(\mathrm{VEB})\end{array}$ & $1 \mathrm{mins}$ & 1 \\
\hline Extension & 72 & $1 \mathrm{mins}$ & 1 \\
\hline Final extension & 72 & $7 \mathrm{mins}$ & 1 \\
\hline
\end{tabular}

\subsection{Agarose Gel Electrophoresis of Extracted Plasmid}

The plasmid isolated from E. coli was resolved using $1 \%$ agarose gel. The gel was constituted by dissolving $1 \mathrm{~g}$ of agarose in $90 \mathrm{ml}$ distilled water in a $250 \mathrm{ml}$ beaker, the beaker was placed in a microwave for 2 minutes to completely dissolve the agarose. To the agarose gel solution, $2.5 \mathrm{ml}$ ethidium bromide (EtBr) was added and swirled gently to mix. The gel solution was poured into a mini horizontal electrophoresis tank with well combs in place and left for 30 minutes to completely solidify. The well combs were carefully removed after the gel had solidified. $1 \mathrm{X}$ TAE (TBE) electrophoresis buffer was added to the electrophoresis tank until the agarose gel was covered.

$5 \mu \mathrm{l}$ of bromophenol blue (tracking dye) was added to $15 \mu \mathrm{l}$ of each genomic DNA isolate and mixed gently. The wells were carefully loaded with $20 \mu$, the electrophoresis tank was closed and the electrodes plugged in, the gel ran for 45 miutes at $100 \mathrm{mV}$. At the end of the run time, power was turned off, electrodes disconnected and the gel was removed from the gel tank and visualized using a Transilluminator at $302 \mathrm{~nm}$. The DNA fragments (bands) were documented employing an electrophoresis gel documentation system.

\section{RESULTS}

A prevalence of $37.7 \%$ (14\%) DEC was observed in the stool samples evaluated while a $53.3 \%$ isolation rate was observed in healthy subjects. ST hospital (60\%) had the highest E. coli isolation percentage while the least E. coli yield was in GH (34.3\%) Table 4.

Table-4. Distribution of diarrheic stool samples evaluated in Minna, Nigeria.

\begin{tabular}{c|c|c|c}
\hline Hospital & No. of stool samples & $\boldsymbol{E}$ coli isolated & \% $\boldsymbol{E}$ coli per Source \\
\hline ST & 20 & 12 & 60 \\
\hline IBB & 24 & 13 & 54.2 \\
\hline GH & 70 & 17 & 24.3 \\
\hline TMED & 22 & 7 & 31.8 \\
\hline H & 15 & 8 & 53.3 \\
\hline Total & $\mathbf{1 5 1}$ & $\mathbf{5 7}$ & $\mathbf{3 7 . 7}$ \\
\hline
\end{tabular}

Table-5. Age distribution of diarrheic stool sampled in Minna, Nigeria.

\begin{tabular}{|c|c|c|c|c|c|c|}
\hline Age Group & ST & IBB & GH & TMH & $\mathbf{H}$ & Total (\%) \\
\hline $0-10$ & 1 & $\mathrm{O}$ & 2 & $\mathrm{O}$ & 2 & $5(3.3)$ \\
\hline $11-20$ & 5 & 1 & 6 & 1 & 2 & $15(9.9)$ \\
\hline $21-30$ & 4 & 8 & 20 & 7 & 3 & $42(27.8)$ \\
\hline $31-40$ & 2 & 5 & 18 & 7 & 5 & $37(24.5)$ \\
\hline $41-50$ & 3 & 2 & 12 & 4 & 1 & $22(14.6)$ \\
\hline $51-60$ & 2 & 5 & 5 & 3 & 2 & $17(11.3)$ \\
\hline $61-70$ & 3 & 3 & 3 & $\mathrm{O}$ & $\mathrm{O}$ & $9(6)$ \\
\hline$\geq 71$ & $\mathrm{O}$ & $\mathrm{O}$ & 4 & $\mathrm{O}$ & $\mathrm{O}$ & $4(2.6)$ \\
\hline Total & 20 & 24 & 70 & 22 & 15 & $151(100)$ \\
\hline
\end{tabular}
$\mathrm{H}=$ Healthy subjects. 
Within the environment evaluated, age groups $21-30(27.8 \%)$ and $31-40(24.5 \%)$ had the highest E. coli isolation rate. Age groups $\geq 71(2.6 \%)$ and $0-10$ (3.3\%) had the least E. coli isolation rate Table 5. Females (64.9\%) were the most affected with diarrhea in Minna compared to their male counterparts (35.1\%) Table 6.

Table-6. Gender distribution of diarrhea stool samples evaluated in Minna, Nigeria.

\begin{tabular}{|c|c|c|c|c|c|c|}
\hline Gender & ST & IBB & GH & ТМH & $\mathbf{H}$ & Total (\%) \\
\hline Male & 8 & 10 & 23 & 6 & 6 & $53(35.1)$ \\
\hline Female & 12 & 14 & 47 & 16 & 9 & $98(64.9)$ \\
\hline Total & 20 & 24 & 70 & 22 & 15 & $151(100)$ \\
\hline
\end{tabular}

\subsection{Antibiotics Susceptibility Profile of Diarrheagenic E. coli}

The E.coli isolates were significantly resistant to most of the beta-lactams tested especially $3^{\text {rd }}$ generation cephalosporins [Cefotaxime (98.2\%), cefuroxime (93\%), ceftazidime (84.2\%), Augmentin (70.2\%), Amoxicillin $(59.6 \%)]$. Also observed was resistance to other classes of antibiotics such as quinolones [pefloxacine (56.1), ciprofloxacin (54.4\%), and ofloxacin (45.6)], chloramphenicol (61.4\%), cotrimoxazole (61.4\%). The isolates were observed to show high percentage susceptibility to tetracycline (77.2\%), streptomycin (56.1\%), ofloxacin (54.4\%), and gentamicin $(52.6 \%)$ as shown in Figure 2.

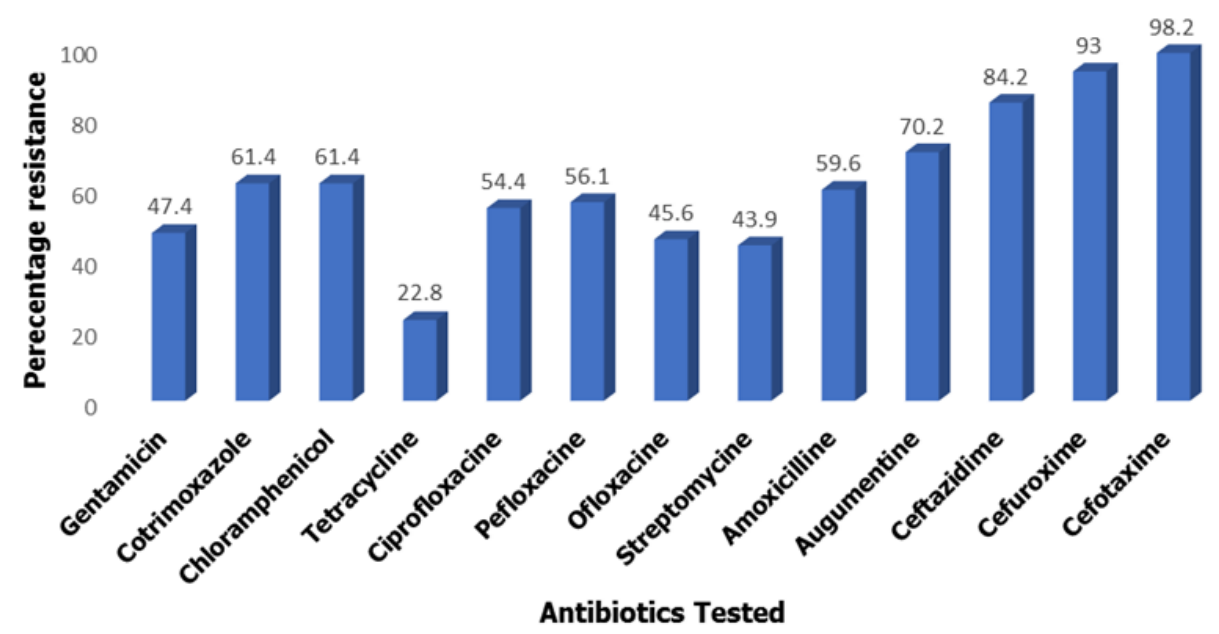

Figure-2. Antibiotics Susceptibility Profile of Diarrheagenic E. coli.

The graph below showed that $98.2 \%$ of the diarrheagenic E. coli had MARI $\geq 0.3$ Figure 3 .

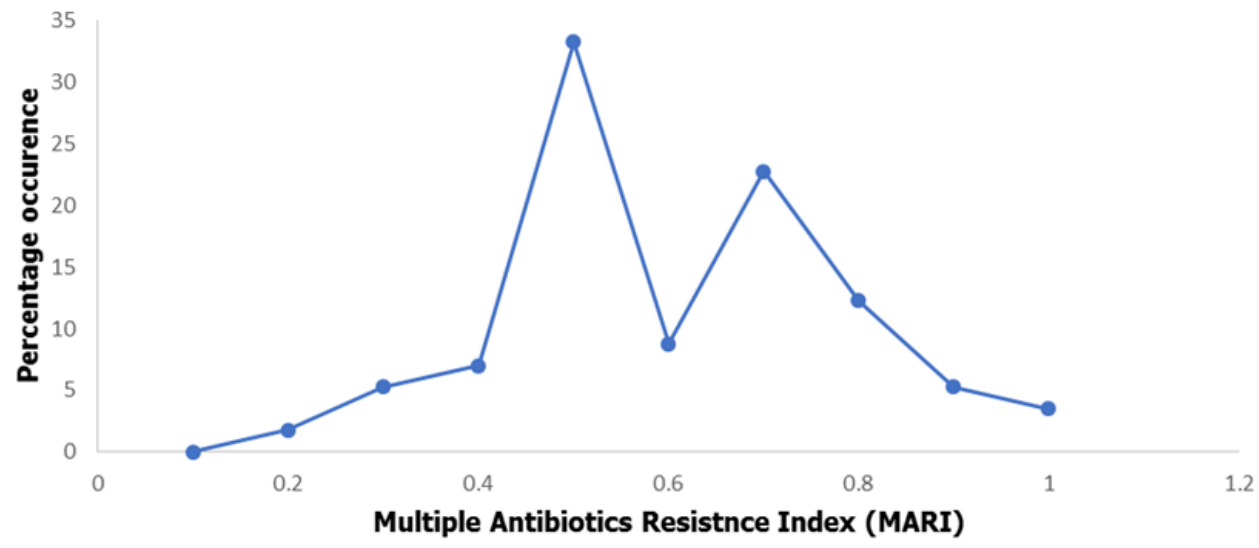

Figure-3. Multiple Antibiotics Resistance Index (MARI). 
The International Journal of Biotechnology, 202 1, 10(2): 52-68

Table-7. Resistant pattern and percentage multidrug resistance of E. coli Isolated from diarrheic patients in Minna, Nigeria

\begin{tabular}{|c|c|c|c|c|c|}
\hline $\mathbf{S} / \mathbf{N}$ & Isolate & Resistant Pattern & NART & CART & LR \\
\hline 1 & $\mathrm{~S} 52$ & $\begin{array}{l}\text { CN, TE, C, SXT, CPX, S, OFX, PEF, AM, } \\
\text { AU, CXM, CTX, CAZ }\end{array}$ & 13 & 7 & MDR \\
\hline 2 & $\mathrm{~S} 73$ & AM, CAZ, CTX, CXM & 4 & 1 & NMDR \\
\hline 3 & $\mathrm{~S} 44$ & $\begin{array}{l}\text { CN, SXT, C, PEF, OFX, S, AM, AU, CAZ, } \\
\text { CTX, CXM }\end{array}$ & 11 & 6 & MDR \\
\hline 4 & $\mathrm{~S} 42$ & CN, SXT, C, AU, CTX, CXM & 6 & 4 & MDR \\
\hline 5 & $\mathrm{~S} 46$ & $\begin{array}{l}\text { CN, SXT, TE, CPX, OFX, S, AM, AU, CAZ, } \\
\text { CTX, CXM }\end{array}$ & 11 & 6 & MDR \\
\hline 6 & S79 & SXT, OFX, S, AM, AU, CTX, CXM & 7 & 4 & MDR \\
\hline 7 & $\mathrm{~S} 1$ & $\begin{array}{l}\text { CN, TE, C, SXT, CPX, S, OFX, PEF, AM, } \\
\text { AU, CXM, CTX, CAZ }\end{array}$ & 13 & 7 & MDR \\
\hline 8 & $\mathrm{~S} 81$ & CN, SXT, AM, AU, CTX, CXM & 6 & 3 & MDR \\
\hline 9 & HS1 & CN, C, TE, AM, CAZ, CTX, CXM & 7 & 4 & MDR \\
\hline 10 & HS3 & CN, SXT, C, OFX, S, AU, CAZ, CTX, CXM & 9 & 6 & MDR \\
\hline 11 & HS7 & $\begin{array}{l}\text { CN, SXT, C, TE, PEF, OFX, S, AM, AU, } \\
\text { CAZ, CTX, CXM }\end{array}$ & 12 & 7 & MDR \\
\hline 12 & $\mathrm{~S} 80$ & $\begin{array}{l}\text { CN, CPX, PEF, OFX, AM, AU, CAZ, CTX, } \\
\text { CXM }\end{array}$ & 9 & 3 & MDR \\
\hline 13 & HS10 & CN, PEF, OFX, S, AM, AU, CTX & 7 & 4 & MDR \\
\hline 14 & $\mathrm{~S} 22$ & C, TE, CPX, CAZ, CTX, CXM & 6 & 4 & MDR \\
\hline 15 & $\mathrm{~S} 5$ & C, CPX, PEF, S, AM, AU, CAZ, CTX, CXM & 9 & 4 & MDR \\
\hline 16 & $\mathrm{~S} 21$ & $\begin{array}{l}\text { C, TE, CPX, S, OFX, PEF, AM, CXM, CTX, } \\
\text { CAZ }\end{array}$ & 6 & 5 & MDR \\
\hline 17 & $\mathrm{~S} 4$ & $\begin{array}{l}\text { TE, C, SXT, CPX, S, OFX, PEF, AM, AU, } \\
\text { CXM, CTX, CAZ }\end{array}$ & 12 & 6 & MDR \\
\hline 18 & S31 & CXM, CTX, CAZ, TE, C & 5 & 3 & MDR \\
\hline 19 & HS9 & CXM, AM, CAZ, CTX, CPX, C, SXT & 7 & 4 & MDR \\
\hline 20 & S8 & CN, C, S, AU, CAZ, CTX, CXM & 7 & 4 & MDR \\
\hline 21 & S7 & CN, SXT, S, AM, AU, CAZ, CTX, CXM & 8 & 4 & MDR \\
\hline 22 & $\mathrm{~S} 12$ & SXT, C, CPX, PEF, S, AM, CAZ, CTX, CXM & 9 & 4 & MDR \\
\hline 23 & $\mathrm{~S} 24$ & CN, SXT, S, AM, CAZ, CTX, CXM & 7 & 4 & MDR \\
\hline 24 & $\mathrm{~S} 40$ & AU, CAZ, CTX, CXM & 4 & 1 & NMDR \\
\hline 25 & $\mathrm{~S} 114$ & $\begin{array}{l}\text { SXT, C, TE, CPX, PEF, S, OFX, AM, CXM, } \\
\text { CTX, CAZ }\end{array}$ & 11 & 6 & MDR \\
\hline 26 & S3 & $\begin{array}{l}\text { CN, C, SXT, CPX, PEF, S, OFX, CXM, CTX, } \\
\text { CAZ }\end{array}$ & 10 & 6 & MDR \\
\hline 27 & S37 & CN, C, PEF, OFX, AU, CAZ, CTX, CXM & 8 & 4 & MDR \\
\hline 28 & $\mathrm{~S} 28$ & SXT, CPX, OFX, CTX, CXM & 5 & 3 & MDR \\
\hline 29 & S32 & CN, SXT, TE, AM, AU, CXM & 6 & 4 & MDR \\
\hline 30 & $\mathrm{~S} 115$ & CN, C, PEF, S, AM, AU, CAZ, CTX, CXM & 9 & 5 & MDR \\
\hline 31 & $\mathrm{~S} 113$ & CN, SXT, C, S, AM, AU, CAZ, CTX, CXM & 9 & 5 & MDR \\
\hline 32 & HS11 & CN, C, PEF, OFX, AM, AU, CAZ, CTX, CXM & 9 & 4 & MDR \\
\hline 33 & S38 & SXT, PEF, AU, CAZ, CTX, CXM & 6 & 3 & MDR \\
\hline 34 & HS6 & CN, CPX, TE, C, SXT, C, S, AU, AM, CXM & 10 & 7 & MDR \\
\hline 35 & $\mathrm{~S} 118$ & $\begin{array}{l}\text { CXM, CTX, CAZ, AU, AM, OFX, PEF, SXT, } \\
\text { CN }\end{array}$ & 9 & 4 & MDR \\
\hline 36 & $\mathrm{~S} 117$ & CXM, CTX, CAZ, AU, AM, TE, C, SXT & 8 & 4 & MDR \\
\hline 37 & $\mathrm{~S} 55$ & CN, SXT, PEF, AU, CAZ, CTX, CXM & 7 & 4 & MDR \\
\hline 38 & S51 & SXT, AM, AU, CAZ, CTX, CXM & 6 & 2 & NMDR \\
\hline 39 & S54 & CPX, CAZ, CTX, CXM & 4 & 2 & NMDR \\
\hline 40 & $\mathrm{~S} 50$ & SXT, C, PEF, OFX, AU, CAZ, CTX, CXM & 8 & 4 & MDR \\
\hline 41 & S61 & CXM, CTX, CAZ, AU, S, PEF, CPX & 7 & 3 & MDR \\
\hline 42 & $\mathrm{~S} 41$ & CXM, CTX, CAZ, AU, AM, S, C, SXT, CN & 9 & 5 & MDR \\
\hline 43 & S57 & $\begin{array}{l}\text { AU, S, CTX, CAZ, CXM, C, CN, SXT, PEF, } \\
\text { CPX, OFX }\end{array}$ & 11 & 6 & MDR \\
\hline 44 & S71 & $\begin{array}{l}\text { CXM, CTX, CAZ, AU, AM, S, OFX, CPX, } \\
\text { TE, C, SXT, CN }\end{array}$ & 12 & 7 & MDR \\
\hline 45 & $\mathrm{HS} 2$ & CXM, CTX, CAZ, AU, OFX, PEF, CPX & 7 & 2 & NMDR \\
\hline 46 & $\mathrm{~S} 14$ & CXM, CTX, CAZ, AU, PEF, CLX, C, SXT & 8 & 4 & MDR \\
\hline
\end{tabular}


The International Journal of Biotechnology, 202 1, 10(2): 52-68

\begin{tabular}{l|l|l|c|c|c}
\hline 47 & S20 & $\begin{array}{l}\text { CXM, CTX, CAZ, AU, OFX, PEF, CPX, C, } \\
\text { SXT }\end{array}$ & 9 & 4 & MDR \\
\hline 48 & S10 & CXM, CTX, CAZ, AU, AM, CPX, TE, C, SXT & 9 & 5 & MDR \\
\hline 49 & S9 & CXM, CTX, CAZ, PEF, CPX, C & 6 & 3 & MDR \\
\hline 50 & S19 & SXT, C, CPX, CAZ, CTX, CXM & 4 & MDR \\
\hline 51 & S127 & $\begin{array}{l}\text { CXM, CTX, CAZ, AU, AM, S, OFX, PEF, } \\
\text { CPX }\end{array}$ & 9 & 3 & MDR \\
\hline 52 & S26 & CN, AM, CPX, AM, CAZ, CTX, CXM & 6 & 3 & MDR \\
\hline 53 & S29 & CPX, CXM & 2 & 2 & NMDR \\
\hline 54 & S76 & SXT, CPX, PEF, OFX, CXM, CTX & 6 & 3 & MDR \\
\hline 55 & S67 & $\begin{array}{l}\text { CPX, C, SXT, PEF, OFX, AU, AM, CXM, } \\
\text { CTZ, CAZ }\end{array}$ & 10 & 4 & MDR \\
\hline 56 & S132 & CPX, PEF, AU, CAZ, CXM & 5 & 2 & NMDR \\
\hline 57 & S58 & $\begin{array}{l}\text { C, CPX, PEF, OFX, AM, AU, CAZ, CTX, } \\
\text { CXM }\end{array}$ & 9 & 3 & MDR \\
\hline
\end{tabular}

Keys: NART $=$ number of antibiotics resistant to, CART $=$ classification of antibiotics resistant to, LR $=$ level of resistance, MDR $=$ multidrug resistance, $\mathrm{CN}=$ gentamicin, $\mathrm{SXT}=$ cotrimoxazole, $\mathrm{C}=$ chloramphenicol, $\mathrm{TE}=$ tetracycline, $\mathrm{CPX}=$ ciprofloxacin, $\mathrm{PEF}=$ pefloxacin, $\mathrm{OFX}=$ ofloxacin, $\mathrm{S}=$ streptomycin, $\mathrm{AM}=$ amoxicillin, $\mathrm{AU}=$ augmentin, $\mathrm{CAZ}=$ ceftazidime, $\mathrm{CTX}=$ cefotaxime, $\mathrm{CXM}=$ cefuroxime.

A high percentage $[87.7 \%(50)]$ of the isolates were multidrug-resistant (MDR i.e. resistant to more than 3 classes of antibiotics tested). The isolates had various patterns, 36.8\% (21) of the isolates were resistant to all the beta-lactams tested (AM, AU, CAZ, CTX, CXM), and were also MDR; of which 29.8\% (17) were resistant to $\geq 5$ classes of antibiotics Table 7 .

A significant percentage $[47.6 \%(10)]$ of the DEC isolates that were MDR, especially those resistant to more than 5 classes of antibiotics tested, exhibited phenotypical characteristics of ESBL (Table 8) and their resistance pattern is presented in Table 9 below.

Table-8. Distribution of extended spectrum $\beta$-lactamase among DEC with multidrug resistance profile.

\begin{tabular}{|c|c|c|c|c|c|c|}
\hline $\mathbf{S} / \mathbf{N}$ & ISOLATE & $\mathrm{AMC}$ & $\mathrm{CAZ}$ & CTX & CXM & ESBL \\
\hline 1 & $\mathrm{~S} 52$ & 22 & 25 & 24 & 24 & + \\
\hline 2 & $\mathrm{~S} 44$ & 23 & 23 & 22 & 20 & + \\
\hline 3 & $\mathrm{~S} 46$ & 10 & 6 & 9 & 6 & - \\
\hline 4 & $\mathrm{~S} 1$ & 14 & 6 & 6 & 6 & - \\
\hline 5 & HS3 & 24 & 27 & 22 & 25 & + \\
\hline 6 & $\mathrm{HS}_{7}$ & 17 & 18 & 14 & 14 & + \\
\hline 7 & $\mathrm{H} 21$ & 17 & 10 & 15 & 12 & + \\
\hline 8 & $\mathrm{~S} 4$ & 20 & 19 & 17 & 17 & + \\
\hline 9 & $\mathrm{~S} 114$ & 17 & 15 & 15 & 18 & + \\
\hline 10 & S3 & 10 & 6 & 6 & 6 & - \\
\hline 11 & $\mathrm{~S} 115$ & 24 & 21 & 22 & 23 & + \\
\hline 12 & $\mathrm{~S} 113$ & 23 & 22 & 26 & 23 & + \\
\hline 13 & HS6 & 13 & 8 & 6 & 10 & - \\
\hline 14 & $\mathrm{~S} 41$ & 12 & 6 & 14 & 6 & - \\
\hline 15 & $\mathrm{~S} 57$ & 12 & 6 & 14 & 6 & - \\
\hline 16 & $\mathrm{~S} 71$ & 9 & 6 & 10 & 6 & - \\
\hline 17 & $\mathrm{~S} 14$ & 12 & 6 & 14 & 6 & - \\
\hline 18 & $\mathrm{~S} 20$ & 6 & 6 & 6 & 6 & - \\
\hline 19 & $\mathrm{~S} 10$ & 22 & 25 & 24 & 24 & + \\
\hline 20 & $\mathrm{~S} 57$ & 12 & 6 & 8 & 10 & - \\
\hline 21 & S71 & 15 & 6 & 14 & 9 & - \\
\hline
\end{tabular}

DNA extraction was done on the 10 isolates that showed phenotypic ESBL production. Half [50\% (5)] of the isolates harbored the CTXM genes that amplified at 593 base pair (Plate 1). 90\% of the isolated encoded the TEM gene (Plate 2), none of the isolates had SHV (Plate 3), 40\% expressed OXA gene (Plate 4), all (100\%) the isolate harbored VEB (Plate 5) while only 50\% had the PER gene (Plate 6). 
The International Journal of Biotechnology, 202 1, 10(2): 52-68

Table-9. Resistant patterns of multidrug-resistant DEC that expressed ESBL phenotypically.

\begin{tabular}{|c|c|c|c|c|c|}
\hline $\mathbf{S} / \mathbf{N}$ & Isolate & Resistant Pattern & NART & CART & LR \\
\hline 1 & $\mathrm{~S} 52$ & $\begin{array}{l}\text { CN, TE, C, SXT, CPX, S, OFX, PEF, AM, AU, CXM, } \\
\text { CTX, CAZ }\end{array}$ & 13 & 7 & MDR \\
\hline 2 & $\mathrm{~S} 44$ & CN, SXT, C, PEF, OFX, S, AM, AU, CAZ, CTX, CXM & 11 & 6 & MDR \\
\hline 3 & $\mathrm{~S} 21$ & $\begin{array}{l}\text { CN, SXT, TE, CPX, OFX, S, AM, AU, CAZ, CTX, } \\
\text { CXM }\end{array}$ & 11 & 6 & MDR \\
\hline 4 & $\mathrm{~S} 1$ & $\begin{array}{l}\text { CN, TE, C, SXT, CPX, S, OFX, PEF, AM, AU, CXM, } \\
\text { CTX, CAZ }\end{array}$ & 13 & 7 & MDR \\
\hline 5 & HS3 & CN, SXT, C, OFX, S, AU, CAZ, CTX, CXM & 9 & 6 & MDR \\
\hline 6 & $\mathrm{HS} 7$ & $\begin{array}{l}\text { CXM, CTX, CAZ, AU, AM, S, OFX, PEF, TE, C, SXT, } \\
\text { CN }\end{array}$ & 12 & 7 & MDR \\
\hline 7 & $\mathrm{~S} 21$ & CXM, CTX, CAZ, AM, S, OFX, PEF, CPX, TE, C & 6 & 5 & MDR \\
\hline 8 & $\mathrm{~S} 4$ & $\begin{array}{l}\text { CXM, CTX, CAZ, AU, AM, S, OFX PEF, CPX TE, C, } \\
\text { SXT }\end{array}$ & 12 & 6 & MDR \\
\hline 9 & $\mathrm{~S} 114$ & $\begin{array}{l}\text { CXM, CTX, CAZ, AM, S, OFX, PEF, CPX, TE, C, } \\
\text { SXT }\end{array}$ & 11 & 6 & MDR \\
\hline 10 & S3 & $\begin{array}{l}\text { CXM, CTX, CAZ, AM, S, OFX, PEF, CPX, C, SXT, } \\
\text { CN }\end{array}$ & 10 & 6 & MDR \\
\hline
\end{tabular}

ofloxacin, $\mathrm{S}=$ streptomycin, $\mathrm{AM}=$ amoxicillin, $\mathrm{AU}=$ augmentin, $\mathrm{CAZ}=$ ceftazidime, $\mathrm{CTX}=$ cefotaxime, $\mathrm{CXM}=$ cefuroxime.

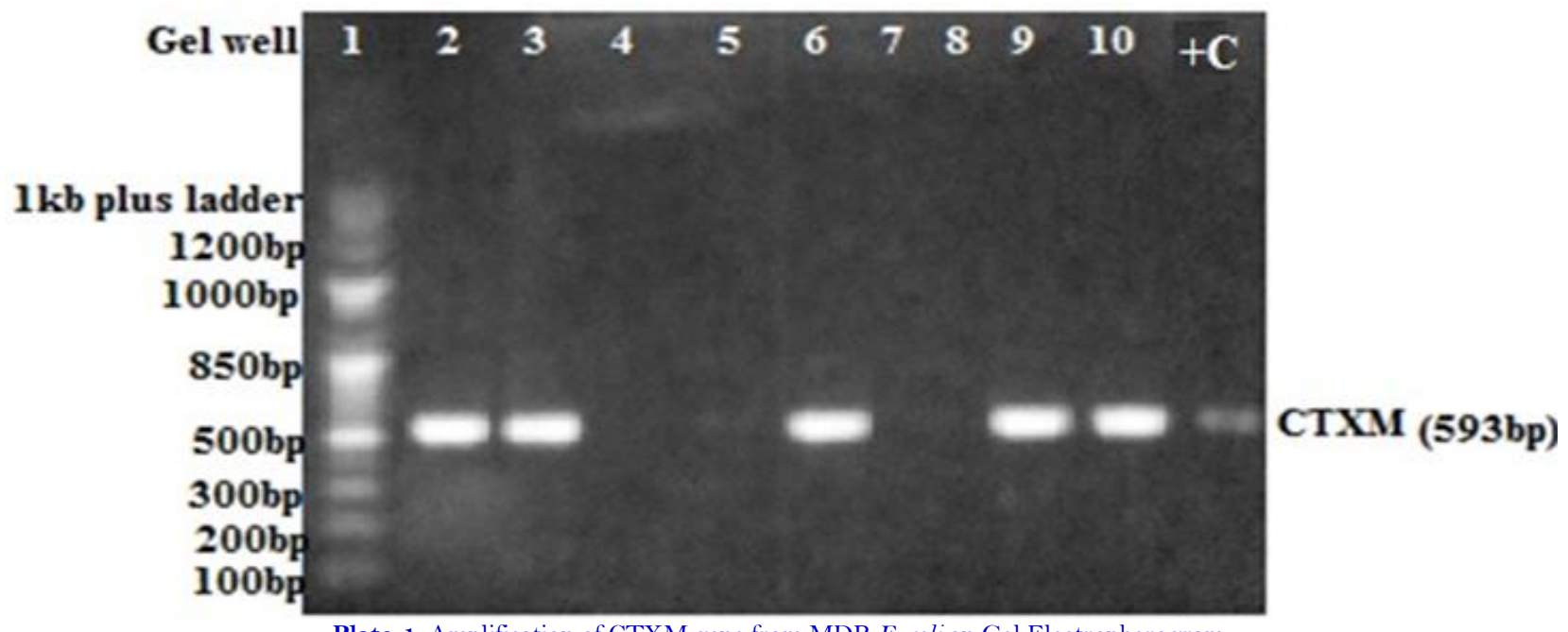

Plate-1. Amplification of CTXM gene from MDR E. coli on Gel Electropherogram.

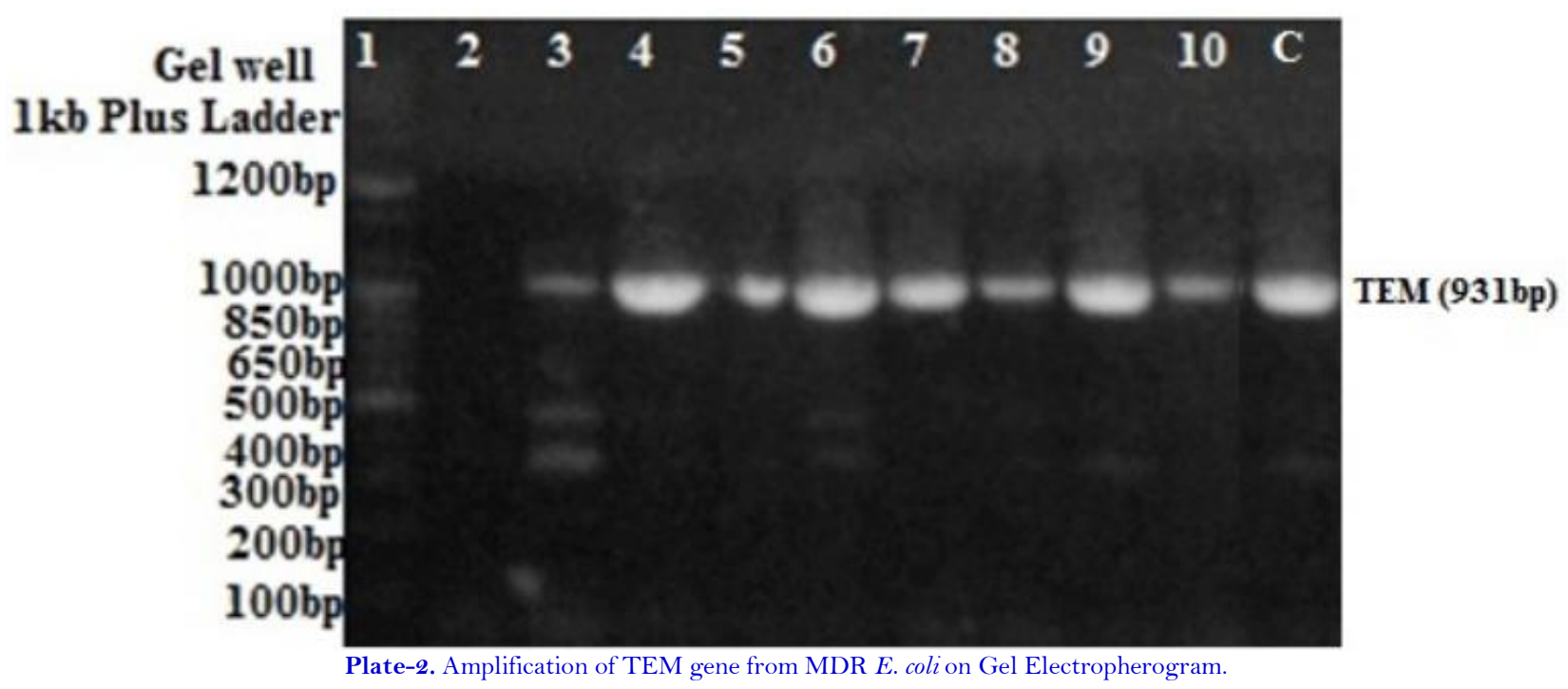



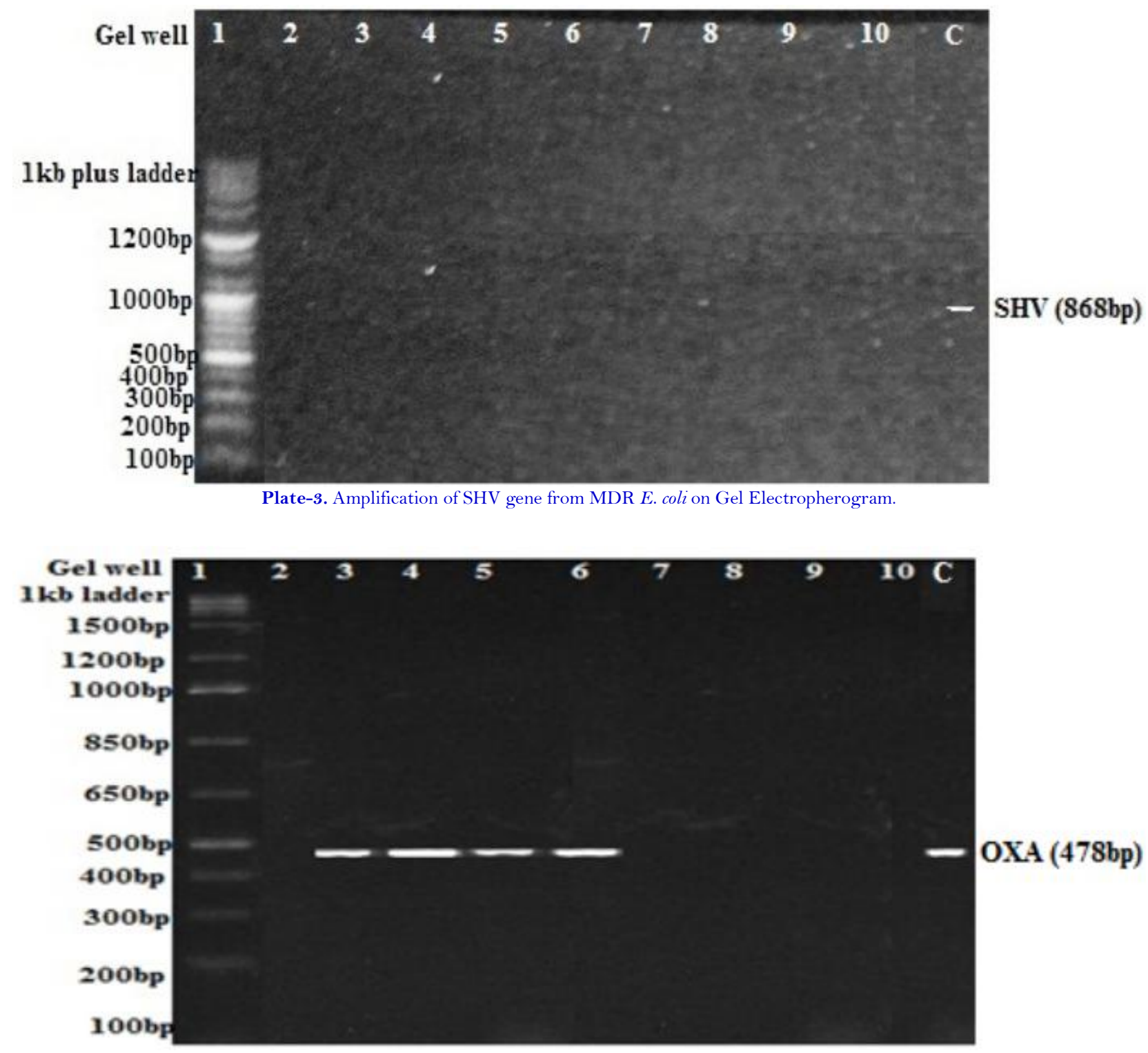

Plate-4. Amplification of OXA gene from MDR E. coli on Gel Electropherogram.

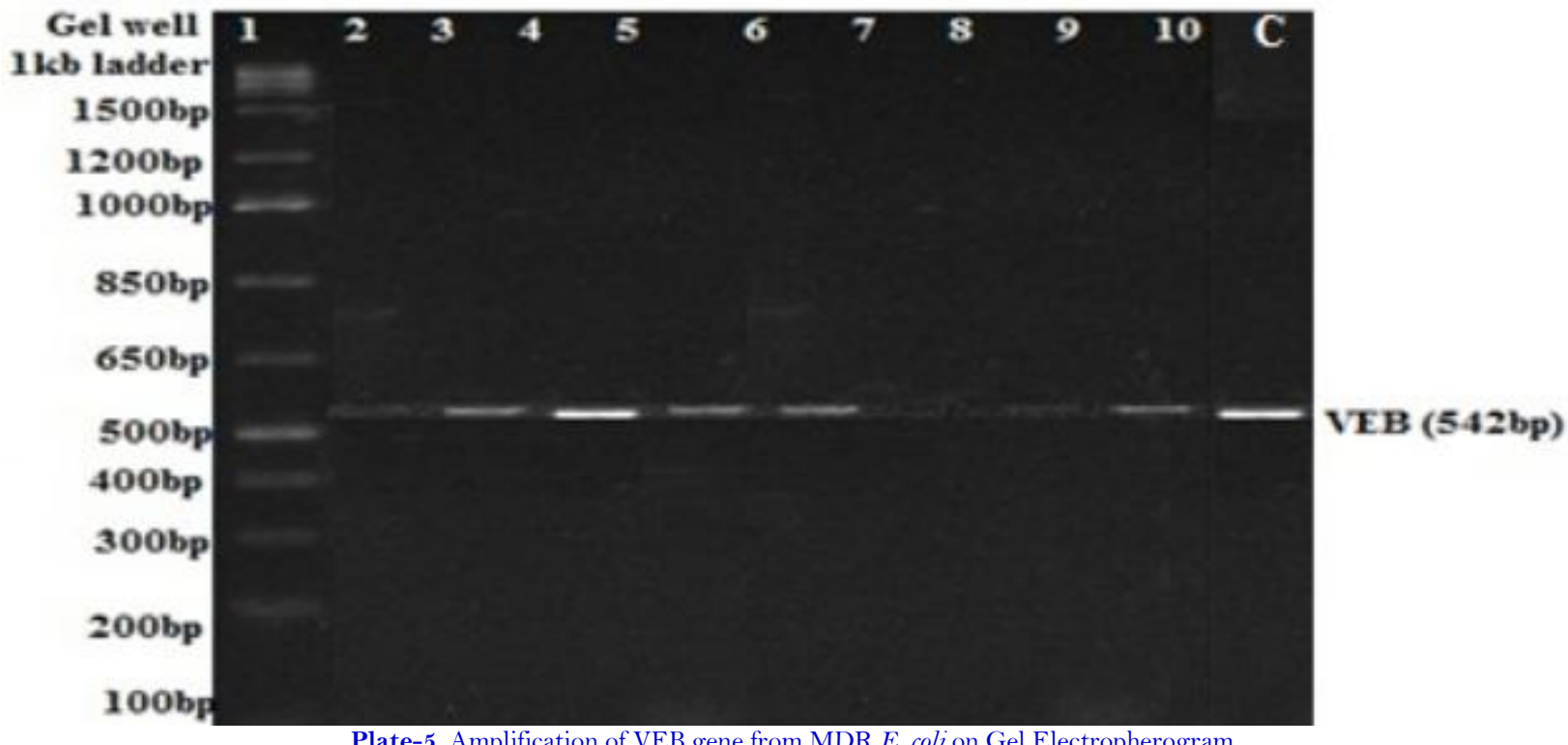

Plate-5. Amplification of VEB gene from MDR E. coli on Gel Electropherogram. 
The International Journal of Biotechnology, 202 1, 10(2): 52-68

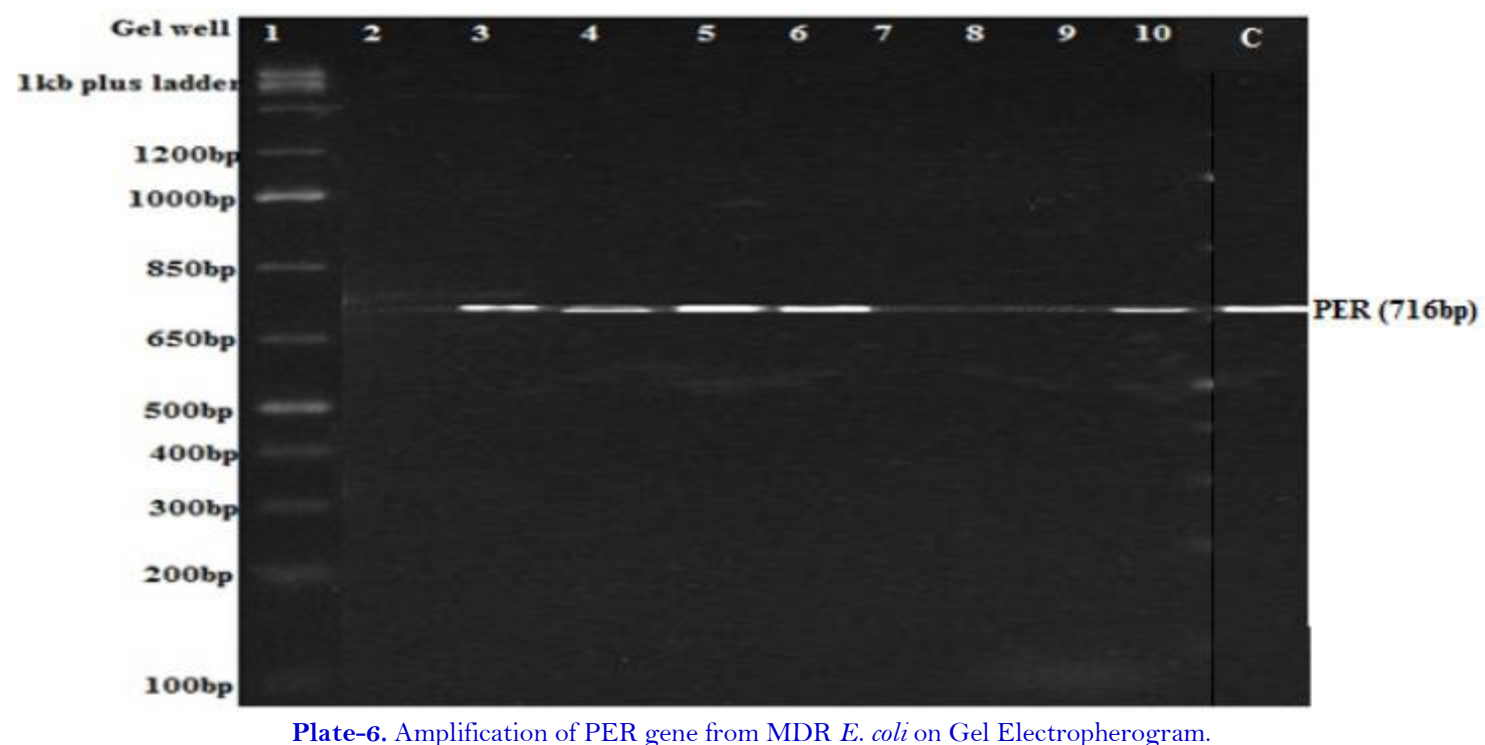

\section{DISCUSSION}

According to the 2017 global disease burden estimation, diarrhea accounts for one of the major reasons for hospital visits amongst all ages in developing countries with E. coli and Rotavirus documented as the most reported etiological agents. E.coli and Rotavirus are reported to be responsible for above 1 million deaths and about $4 \%$ of the total global disability-adjusted life-years (DALYS) per year with the highest impact among infants and young children (Khalil et al., 2018; WHO, 2017). A study by Ifeanyi et al. (2015); Onanuga et al. (2014) on children had reported a recovery rate of $18.4 \%$ and $12.8 \%$ among children with diarrhea in Gwagwalada, Federal Capital Territory, Abuja. Our findings in all age groups observed a total prevalence of $37.7 \%$ diarrheagenic E. coli from the stools sampled in Minna. These results agree with other findings within Nigeria that E. coli is a significant etiological agent of diarrhea (Presterl et al., 2003). However, the prevalence is less than $44.7 \%$ reported by Nweze (2010) in South East (Onitsha and Enugu) and 88\% reported by Adenipekun et al. (2016) in the South west (Lagos). According to Zhou et al. (2018) who studied the seasonal distribution of DEC, reported that this strain tends to infect young children during summer or autumn. Further analysis of the results showed a significant diarrheagenic E. coli isolation rate (53.3\%) among healthy individuals in the areas sampled. These asymptomatic carriers according to Onanuga et al. (2014) are likely to be potential spreaders of infectious $E$. coli to susceptible individuals in the study area. However, studies have shown that factors triggering diarrhea in humans abound but the poor quality of food, water, hygiene, and sanitation in developing contributes immensely to high rates commonly reported. Comparative evaluation of age with diarrhea within Minna showed that age groups $21-30$ years (27.8\%) and $31-40$ years $(24.5 \%)$ had the highest $E$. coli isolation rate while age groups $\geq 71(2.6 \%)$ and $0-10$ years $(3.3 \%)$ had the least $E$. coli isolation rate (Table 5). Although the later groups are more susceptible to infection due to low immunity and adaptation, the Centers for Disease Control and Prevention (n.d) had acknowledged that diarrhea is not only attributed to microbial infection rather other factors such as pre-formed microbial toxins, consuming contaminated foods, food allergies, food intolerances (celiac disease or lactose intolerance), some medications, radiation therapy and malabsorption of food (poor absorption). According to Troeger et al. (2018), diarrhea was the eighth leading cause of death among all age groups in 2016 and the study conducted by (Akinjogunla, Eghafona, \& Ekoi, 2009); Gupta, Sarker, Rout, Mondal, and Pal (2015) indicates that the prevalence of diarrhea gradually decreased with increasing age. This is contrary to the results observed in this study as diarrheagenic E. coli was most common within adults (age 21-40 years). This could be attributed to the report of Barr and Smith (2014) who observed that acute diarrhea associated with bacteria in adults is on the increase globally and it's triggered by increases in travel, co-morbidities, and foodborne illness. Studies conducted by Akinjogunla et al. (2009) in Uyo 
(Southern Nigeria) and Nweze (2010) in South-Eastern Nigeria (Onitsha and Enugu) had noted that females (53.33\%) had more diarrheagenic E. coli than males (46.67\%), which supports our findings in Minna. Contrary findings were reported by Olorunshola, Smith, and Coker (2000) in Lagos; Yilgwan and Okolo (2012) in Jos; and Abuzerr et al. (2019) in Gaza who had reported that males are more infected with diarrhea than females. The prevalence of diarrheagenic E. coli in different gender is geographically and environmentally influenced. A study by Nweze (2010) showed that gender had no effect on the distribution of diarrheagenic bacteria but individual hygiene plays an important role in the infection rates. Most studies on diarrheagenic E. coli have acknowledged antibiotic resistance to commonly prescribed drugs especially the beta-lactams in alarming proportions worldwide due to misuse of antibiotics which do elicit selective force in the bacteria population (Ugwu, Edeani, Ejikeugwu, Okezie, \& Ejiofor, 2017). This was also observed in our study as the E.coli isolates had significant resistance to most of the beta-lactams tested especially to $3^{\text {rd }}$ generation cephalosporines [Cefotaxime (98.2\%), cefuroxime (93\%), ceftazidime (84.2\%), Augmentin (70.2\%), Amoxicillin (59.6\%)]. Significant resistance to other classes of antibiotics such as quinolones [pefloxacin (56.1), ciprofloxacin (54.4\%), and ofloxacin (45.6)], chloramphenicol (61.4\%), cotrimoxazole $(61.4 \%)$ were also detected. The isolates were observed to show high percentage susceptibility to Tetracycline (77.2\%), Streptomycin (56.1\%), Ofloxacin (54.4\%), and Gentamicin (52.6\%). This finding agrees with studies by Ugwu et al. (2017) in Awka Nigeria and Zhang et al. (2018) in China who observed the trend in rising resistance expressed by E. coli. Although the WHO guidelines (WHO, 2017) prohibits the use of antibiotics for the treatment of diarrhea especially for undiagnosed cases in Minna Nigeria, antibiotics are often used due to lack of resource personnel, paucity of funds, and impatience in awaiting diagnostic laboratory results (Quan-Cheng, Jian-Guo, Xiang-Hua, \& Zhen-Zhen, 2016). These underlining factors have contributed immensely to changes in human microecological factors as observed in nutrition metabolism causing a vast flora imbalance, growth, and development, biological antagonism, and immunity leading to double infections and a decrease in host resistance to infection (Knoop, McDonald, Kulkarni, \& Newberry, 2016). According to Kao et al. (2016), the resistant characteristics expressed by the E.coli isolates suggest the production of extended-spectrum beta-lactamase enzymes (ESBL), which confers resistance to drugs such as cephalosporins, synthetic oxyimino- $\beta$-lactams and penicillin. These attributes have been reported to influence an increase in treatment costs and long hospital stays.

A significant percentage $(98.2 \%)$ of the isolates had MARI $\geq 0.3$. This report is similar to the findings of Igwe, Musa, Olayinka, Ehnimidu, and Onaolapo (2015) who also detected a high MARI among DEC in Zaria, Nigeria. This indicates that the DEC isolates emanated from a source with high-risk contamination where antibiotics are often used. It also shows that large proportions of the bacterial isolates may have been previously exposed to some antibiotics tested in the study (Igwe et al., 2016). A high percentage $[87.7 \%(50)$ of the isolates had multidrugresistant (MDR) characteristics i.e. resistant to more than three classes of antibiotics tested. The isolates had various patterns; $36.8 \%$ (21) of the isolates showed resistance to all the beta-lactams screened (AM, AU, CAZ, CTX, CXM), and were also MDR; of which $29.8 \%$ (17) were resistant to $\geq 5$ classes of antibiotics. Studies by Bako et al. (2018) in Burkina Faso and Zhou et al. (2018) in China reported that about 91\% and 66.7\% of DEC strains were multidrug-resistant (MDR) while Eltai, Al Thani, Al Hadidi, Al Ansari, and Yassine (2020) study in Qatar reported 39.5\%. Although the percentage expression of MDR varies across different locations, these studies showcase the possibility of isolating MDR from DEC, which concurs with our finding. This rising resistance profile among the prevalent pathogenic strain of $E$. coli, if allowed to proliferate could pose a significant threat to public health especially among immunocompromised, children, and the elderly. However, the prevalence of DEC is low among the children and elderly in Minna, Nigeria. Further evaluation of results showed that a significant percentage $(47.6 \%)$ of the DEC isolates that were MDR; especially those that exhibited resistance to more than 5 classes of antibiotics tested, produced phenotypic characteristics of ESBL. Molecular analysis of the isolates indicated that $50 \%, 90 \%, 0 \%$ of the isolates harbored the CTXM, TEM, SHV genes respectively while $40 \%, 50 \%$, and $100 \%$ expressed OXA, PER, and VEB genes respectively. A significant percentage of the isolates were also seen encoding 
more than one form of ESBL gene and also multidrug-resistant. This is similar to the report of Zhou et al. (2018) who also observed different multidrug-resistant and plasmid-encoded genes in DEC. The report showed that $60 \%$ of the DEC evaluated possessed carbapenemase genes (2 blaNDM-1 and 1 blaKPC-2) whereas, amongst 30 cephalosporin-resistant DEC, 93.3\% possessed extended-spectrum $\beta$-lactamase (ESBL) genes, with blaTEM1 and blaCTX-M-55 being the prevalent ESBL genes. Bako et al. (2018) acknowledged the possibility of isolating more than one ESBL gene in DEC isolates. The isolation of DEC with varying resistant profiles in Minna is worrisome as it calls for public health emergency and surveillance. Diarrheagenic E.coli with such characteristics are proclaimed to be the major etiological agent responsible for pediatric bacterial diarrhea among children under the age of 5 and the $8^{\text {th }}$ most prominent cause of mortality in developing regions (Soller, Schoen, Bartrand, Ravenscroft, \& Ashbolt, 2010). An increasing prevalence of such pathogenic DEC in an environment could lead to fecal contamination of water bodies in resource-limited environments as they are found in waste from diseased humans and animals and may be transported via the sewer lines and agricultural run-offs (Johannessen, Wennberg, Nesheim, \& Tryland, 2015).

\section{CONCLUSION AND RECOMMENDATIONS}

This research work evaluated the existence of ESBL among DEC in Minna and observed a prevalence of 37.7\% DEC in the stools sampled. Age group $21-30$ years had the highest E. coli isolation rate (27.8\%) while group $\geq 71$ years had the least (2.6\%). Females were more affected (64.9\%) compared to males (35.1\%). The DEC isolates expressed substantial resistance to the majority of the beta-lactams tested and to other classes of antibiotics. High percentages $(98.2 \%$ and $87.7 \%$ ) of DEC had MARI $\geq 0.3$ and MDR respectively. The isolates had varying patterns of resistance with $47.6 \%$ expressing resistance to more than 5 different classes of antibiotics tested and exhibited ESBL characteristics. Molecular evaluation showed that 40\%, 50\%, and 90\%, of the isolates, harbored the OXA, CTXM, and TEM genes respectively while 50\% harbored VEB and PER genes. Periodic prevalence surveillance, especially for DEC and its antibiotic resistance profile would provide valuable information in identifying outbreaks, potential reservoirs, and transmission routes. This will go a long way in reducing infant mortality and morbidity associated with diarrhea in the future. More so, promoting various effective intervention and treatment strategies will assist in the prevention of Diarrhea globally.

Funding: This study received no specific financial support.

Competing Interests: The authors declare that they have no competing interests.

Acknowledgement: All authors contributed equally to the conception and design of the study.

\section{REFERENCES}

Abuzerr, S., Nasseri, S., Yunesian, M., Hadi, M., Mahvi, A. H., Nabizadeh, R., \& Mustafa, A. A. (2019). Prevalence of diarrheal illness and healthcare-seeking behavior by age-group and sex among the population of Gaza strip: A community-based cross-sectional study. BMC Public Health, 19(1), 1-10. Available at: https://doi.org/10.1186/s12889-019-7070-0.

Adenipekun, E. O., Jackson, C. R., Ramadan, H., Iwalokun, B. A., Oyedeji, K. S., Frye, J. G., .. Oluwadun, A. (2016). Prevalence and multidrug resistance of Escherichia coli from community-acquired infections in Lagos, Nigeria. Journal of Infection in Developing Countries, 10(9), 920-931. Available at: https://doi.org/10.3855/jidc.7997.

Akinjogunla, O., Eghafona, N., \& Ekoi, O. (2009). Diarrheagenic escherichia coli (DEC): Prevalence among in and ambulatory patients and susceptibility to antimicrobial chemotherapeutic agents. African Journal of Bacteriology Research, 1(3), 034038.

Archana, C., O'Keefe, C., Cuthill, S. L., Varman, M., \& Kumar, A. (2019). Pediatric escherichia coli infections clinical presentation: History, physical, causes. Retrieved from https://emedicine.medscape.com/article/970451-clinical.

Bako, E., Kagambega, A., Minoungou, G., Nkrumah, N. O., Bagre, T. S., Zongo, C., \& Barro, N. (2018). African journal of bacteriology research antibiotic resistance genes in diarrheagenic Escherichia coli (DEC) isolated from livestock 
organic wastes in Ouagadougou, Burkina Faso. African Journal of Bacteriology Research, 40(4), 56-63. Available at: https://doi.org/10.5897/JBR2018.0266.

Barr, W., \& Smith, A. (2014). Acute diarrhea in adults. American Family Physician, 89(3), 180-189.

Bioneer. (2004). Accuprep ${ }^{\circledR} \quad$ genomic DNA extraction kit. Bioneer. Retrieved from https://us.bioneer.com/Protocol/AccuPrepGenomicDNAextractionKit.pdf.

Bushand, K., \& Jacoby, G. (2010). Updated functional classification of Antimicrobial Agents and Chemotherapy, 54(3), 969-976. Available at: https://doi.org/10.1128/aac.01009-09.

Centers for Disease Control and Prevention. (n.d). Diarrhea: Common illness, global killer. Retrieved from https://www.cdc.gov/healthywater/pdf/global/programs/globaldiarrhea508c.pdf.

Centre for Disease Control and Prevention. (2013). Antibiotic resistance threats in the United States. Retrieved from https://www.cdc.gov/drugresistance/pdf/ar-threats-2013-508.pdf.

Cheesbrough, M. (2006). District laboratory practice in tropical countries. In District Laboratory Practice in Tropical Countries (2nd ed.). CLSI. (2016). Clinical and laboratory standards institute: Performance standards for antimicrobial susceptibility testing supplement M100S.

Croxen, M. A., Law, R. J., Scholz, R., Keeney, K. M., Wlodarska, M., \& Finlay, B. B. (2013). Recent advances in understanding enteric pathogenic Escherichia coli. Clinical Microbiology Revierws, 26(4), 822-880. Available at: https://doi.org/10.1128/cmr.00022-13.

Eltai, N. O., Al Thani, A. A., Al Hadidi, S. H., Al Ansari, K., \& Yassine, H. M. (2020). Antibiotic resistance and virulence patterns of pathogenic Escherichia coli strains associated with acute gastroenteritis among children in Qatar. BMC Microbiology, 20(1), 1-12. Available at: https://doi.org/10.1186/s12866-020-01732-8.

Ghorbani-Dalini, S., Kargar, M., Doosti, A., Abbasi, P., \& Sarshar, M. (2015). Molecular epidemiology of ESBLs genes and multi-drug resistance in diarrheagenic Escherichia Coli strains isolated from adults in Iran. Iranian Journal of Pharmaceutical Research, 14(4), 1257-1262. Available at: https://doi.org/10.22037/ijpr.2015.1753.

Gniadkowski, M. (2008). Evolution of extended-spectrum $\beta$-lactamases by mutation. Clinical Microbiology and Infection, 14, 11-32. Available at: https://doi.org/10.1111/j.1469-0691.2007.01854.x.

Google. (2020). Google earth image. Retrieved from: https://www.google.com/maps/@,9.5860914,6.5713329,22690m/data=!3m1!1e3?hl=nl.

Guessennd, N., Bremont, S., Gbonon, V., Kacou-Ndouba, A., Ekaza, E., Lambert, T., .. Courvalin, P. (2008). Qnr-type quinolone resistance in extended-spectrum beta-lactamase producing enterobacteria in Abidjan, Ivory Coast. Pathologie-Biologie, 56(7-8), 439-446. Available at: https://doi.org/10.1016/j.patbio.2008.07.02.

Gupta, A., Sarker, G., Rout, A. J., Mondal, T., \& Pal, R. (2015). Risk correlates of diarrhea in children under 5 years of age in slums of Bankura, West Bengal. Journal of Global Infectious Diseases, 7(1), 23-29. Available at: https://doi.org/10.4103/0974-777X.150887.

Ifeanyi, C. I. C., Ikeneche, N. F., Bassey, B. E., Al-Gallas, N., Ben, A. R., \& Boudabous, A. (2015). Diarrheagenic Escherichia coli pathotypes isolated from children with diarrhea in the federal Capital Territory Abuja, Nigeria. The Journal of Infection in Developing Countries, 9(02), 165-174. Available at: https://doi.org/10.3855/jidc.5528.

Igwe, J. C., Onaolapo, J. A., Kachallah, M., Nworie, A., Oladipo, H. O., Ojiego, B. O., \& Ibanga, I. A. (2014). Molecular

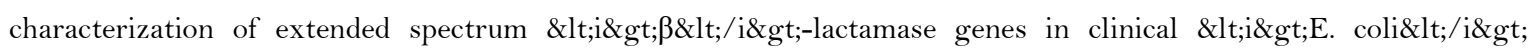
isolates. Journal of Biomedical Science and Engineering, 07(05), 276-285. Available at: https://doi.org/10.4236/jbise.2014.75030.

Igwe, J., Onaolapo, J., Ehimidu, J., Bolaji, R., Tytler, A., Ojiego, B., \& Salihu, M. (2016). Antibiotic susceptibility profile of E. coli serotype 0157:H7 in ABUTH, Zaria, Nigeria. International Journal of Tropical Disease \& Health, 11(1), 1-8. Available at: https://doi.org/10.9734/ijtdh/2016/13112.

Igwe, J. C., Musa, A., Olayinka, B. O., Ehnimidu, J. O., \& Onaolapo, J. A. (2015). Tetracycline resistant genes in E. coli isolated from UTI and diarrhea patients in Zaria, Nigeria. Clinical Microbiology: Open Access. 
Isidean, S., Riddle, M., Savarino, S., \& Porter, C. (2011). A systematic review of ETEC epidemiology focusing on colonization factor and toxin expression. Vaccine, 29(37), 6167-6178. Available at: https://doi.org/10.1016/j.vaccine.2011.06.084.

Johannessen, G. S., Wennberg, A. C., Nesheim, I., \& Tryland, I. (2015). Diverse land use and the impact on (Irrigation) water quality and need for measures - A case study of a Norwegian river. International Journal of Environmental Research and Public Health, 12(6), 6979-7001. Available at: https://doi.org/10.3390/ijerph120606979.

Kantele, A., Lääveri, T., Mero, S., Häkkinen, I. M., Kirveskari, J., Johnston, B. D., \& Johnson, J. R. (2020). Despite predominance of uropathogenic/extraintestinal pathotypes among travel-acquired extended-spectrum $\beta$-lactamase-producing Escherichia coli, the most commonly associated clinical manifestation is travelers' diarrhea. Clinical Infectious Diseases, $7 O(2), 2$ 10-2 18. Available at: https://doi.org/10.1093/cid/ciz 182 .

Kao, C. Y., Udval, U., Huang, Y. T., Wu, H. M., Huang, A. H., Bolormaa, E., \& Wu, J. J. (2016). Molecular characterization of extended-spectrum $\beta$-lactamase-producing Escherichia coli and Klebsiella spp. isolates in Mongolia. Journal of Microbiology, Immunology and Infection, 49(5), 692-700. Available at: https://doi.org/10.1016/j.jmii.2015.05.009.

Khalil, I. A., Troeger, C., Blacker, B. F., Rao, P. C., Brown, A., Atherly, D. E., \& Kang, G. (2018). Morbidity and mortality due to shigella and enterotoxigenic Escherichia coli diarrhoea: The global burden of disease study 1990-2016. The Lancet Infectious Diseases, 18(11), 1229-1240. Available at: https://doi.org/10.1016/S1473-3099(18)30475-4.

Knoop, K. A., McDonald, K. G., Kulkarni, D. H., \& Newberry, R. D. (2016). Antibiotics promote inflammation through the translocation of native commensal colonic bacteria. Gut, 65(7), 1100-1109. Available at: https://doi.org/10.1136/gutjnl-2014-309059.

Krumperman, P. H. (1983). Multiple antibiotic resistance indexing of Escherichia coli to identify high-risk sources of fecal contamination of foods. Applied and Environmental Microbiology, 46(1), 165-170. Available at: https://doi.org/10.1128/aem.46.1.165-170.1983.

Lee, W. C., \& Yeh, K. S. (2017). Characteristics of extended-spectrum $\beta$-lactamase-producing Escherichia coli isolated from fecal samples of piglets with diarrhea in central and southern Taiwan in 2015. BMC Veterinary Research, 13(1), 1-9. Available at: https://doi.org/10.1186/s12917-017-0986-7.

Mandal, A., Sengupta, A., Kumar, A., Singh, U. K., Jaiswal, A. K., Das, P., \& Das, S. (2017). Molecular epidemiology of extendedspectrum $\beta$-lactamase-producing Escherichia coli pathotypes in diarrheal children from low socioeconomic status communities in Bihar, India: Emergence of the CTX-M type. Infectious Diseases: Research and Treatment, 10, 1178633617739018 . Available at: https://doi.org/10.1177/1178633617739018.

Margulieux, K. R., Srijan, A., Ruekit, S., Nobthai, P., Poramathikul, K., Pandey, P., \& Swierczewski, B. E. (2018). Extendedspectrum $\beta$-lactamase prevalence and virulence factor characterization of enterotoxigenic Escherichia coli responsible for acute diarrhea in Nepal from 2001 to 2016. Antimicrobial Resistance \& Infection Control, 7(1), 1-7. Available at: https://doi.org/10.1186/s13756-018-0377-2.

Monstein, H. J., Ostholm-Balkhed, A., Nilsson, M. V., Nilsson, M., Dornbusch, K., \& Nilsson, L. E. (2007). Multiplex PCR amplification assay for the detection of blaSHV, blaTEM, and blaCTX-M genes in Enterobacteriaceae. APMIS: Acta Pathological, Microbiologica, et immunologica Scandinavica, 115(12), 1400-1408. Available at: https://doi.org/10.1111/j.1600-0463.2007.00722.x.

Nweze, E. I. (2010). Aetiology of diarrhoea and virulence properties of diarrhoeagenic Escherichia coli among patients and healthy subjects in Southeast Nigeria. Journal of Health, Population and Nutrition, 28(3), 245-252. Available at: https://doi.org/10.3329/jhpn.v28i3.5551.

Ogefere, H., Ibadin, E., Omoregie, R., \& Ilerhunwa, I. (2016). Prevalence of extended spectrum $\beta$-lactamase among diarrheagenic strains of Escherichia coli among children in Yenagoa, Nigeria. Sokoto Journal of Medical Laboratory Science, 1(1), 7-12.

Olorunshola, I. D., Smith, S. I., \& Coker, A. O. (2000). Prevalence of EHEC O 157:H7 patients with diarrhoea in Lagos, Nigeria. APMIS, 108(11), 761-763. Available at: https://doi.org/10.1034/j.1600-0463.2000.do1-26.x. 
Onanuga, A., Igbeneghu, O., \& Lamikanra, A. (2014). A study of the prevalence of diarrhoeagenic Escherichia coli in children from Gwagwalada, Federal Capital Territory, Nigeria. Pan African Medical Journal, 17, 1-8. Available at: https://doi.org/10.11604/pamj.2014.17.146.3369.

Pandey, P., Bodhidatta, L., Lewis, M., Murphy, H., Shlim, D. R., Cave, W., \& Sornsakrin, S. (2011). Travelers' diarrhea in Nepal: An update on the pathogens and antibiotic resistance. Journal of Travel Medicine, 18(2), 102-108. Available at: https://doi.org/10.1111/j.1708-8305.2010.00475.x.

Pitout, J. D., \& Laupland, K. B. (2008). Extended-spectrum $\beta$-lactamase-producing Enterobacteriaceae: An emerging publichealth concern. The Lancet Infectious Diseases, 8(3), 159-166. Available at: https://doi.org/10.1016/S14733099(08)70041-0.

Presterl, E., Zwick, R. H., Reichmann, S., Aichelburg, A., Winkler, S., Kremsner, P. G., \& Graninger, W. (2003). Frequency and virulence properties of diarrheagenic Escherichia coli in children with diarrhea in Gabon. American Journal of Tropical Medicine and Hygiene, 69(4), 406-410. Available at: https://doi.org/10.4269/ajtmh.2003.69.406.

Quan-Cheng, K., Jian-Guo, W., Xiang-Hua, L., \& Zhen-Zhen, L. (2016). Inappropriate use of antibiotics in children in China. The Lancet, 387(10025), 1273-1274. Available at: https://doi.org/10.1016/s0140-6736(16)30019-8.

Shridhar, P. B., Patel, I. R., Gangiredla, J., Noll, L. W., Shi, X., Bai, J., \& Nagaraja, T. (2018). Genetic analysis of virulence potential of Escherichia coli $\mathrm{O} 104$ serotypes isolated from cattle feces using whole genome sequencing. Frontiers in Microbiology, 9, 341. Available at: https://doi.org/10.3389/fmicb.2018.00341.

Soller, J. A., Schoen, M. E., Bartrand, T., Ravenscroft, J. E., \& Ashbolt, N. J. (2010). Estimated human health risks from ex posure to recreational waters impacted by human and non-human sources of faecal contamination. Water Research, 44(16), 4674-4691. Available at: https://doi.org/10.1016/j.watres.2010.06.049.

Todar, K. (2020). Bacterial resistance to antibiotics. 1-4.

Troeger, C., Blacker, B. F., Khalil, I. A., Rao, P. C., Cao, S., Zimsen, S. R., \& Reiner, R. C. (2018). Estimates of the global, regional, and national morbidity, mortality, and aetiologies of diarrhoea in 195 countries: A systematic analysis for the Global Burden of Disease Study 2016. The Lancet Infectious Diseases, 18(11), 1211-1228. Available at: https://doi.org/10.1016/S1473-3099(18)30362-1.

Ugwu, M., Edeani, G., Ejikeugwu, C., Okezie, U., \& Ejiofor, S. (2017). Antibiotic susceptibility profile of Escherichia coli and Salmonella causing childhood diarrhoea in Awka Municipality, South-Eastern Nigeria. Clinical Microbiology, 6(277), 2. Available at: https://doi.org/10.4172/2327-5073.1000277.

Vipin, M. T. P., \& Sakellaris, H. (2015). Colonization factors of enterotoxigenic escherichia coli. Advances in Applied Microbiology, 90, 155-197. Available at: https://doi.org/10.1016/bs.aambs.2014.09.003.

WHO. (2017). Diarrhoeal disease. Retrieved from https://www.who.int/news-room/fact-sheets/detail/diarrhoeal-disease.

Yilgwan, C. S., \& Okolo, S. N. (2012). Prevalence of diarrhea disease and risk factors in Jos university teaching hospital, Nigeria. Annals of African Medicine, 11(4), 217-221. Available at: https://doi.org/10.4103/1596-3519.102852.

Zhang, S.-X., Zhou, Y.-M., Tian, L.-G., Chen, J.-X., Tinoco-Torres, R., Serrano, E., \& Chen, J.-H. (2018). Antibiotic resistance and molecular characterization of diarrheagenic Escherichia coli and non-typhoidal Salmonella strains isolated from infections in Southwest China. Infectious Diseases of Poverty, 7(1), 1-11. Available at: https://doi.org/10.1 186/s40249018-0427-2.

Zhou, Y., Zhu, X., Hou, H., Lu, Y., Yu, J., Mao, L., \& Sun, Z. (2018). Characteristics of diarrheagenic Escherichia coli among children under 5 years of age with acute diarrhea: A hospital based study. BMC Infectious Diseases, 18(1), 1-10. Available at: https://doi.org/10.1186/s12879-017-2936-1.

Views and opinions expressed in this article are the views and opinions of the author(s), The International Journal of Biotechnology shall not be responsible or answerable for any loss, damage or liability etc. caused in relation to/arising out of the use of the content. 